\title{
MODEL PROYEKSI PENDAPATAN PAJAK KENDARAAN BERMOTOR DAN BEA BALIK NAMA DI DINAS PENDAPATAN DAERAH (DISPENDA) PROVINSI BENGKULU
}

\author{
Karona Cahya Susena \\ Ahmad Soleh \\ Fakultas Ekonomi Universitas Dehasen Bengkulu \\ karona_cs@yahoo.co.uk
}

\begin{abstract}
ABSTRAK
Karona Cahya Susena dan Ahmad Soleh; Penelitian ini bertujuan untuk menggambarkan model proyeksi dalam menentukan pendapatan pajak Kendaraan Bermotor dan Bea Balik Nama di Dinas Pendapatan Daerah (Dispenda) Provinsi Bengkulu tahun 2016-2020. Hasil penelitian ini menunjukkan bahwa Metode Trend Least Square lebih tepat di gunakan untuk menetapkan target tahun 2016-2020, dimana perhitungan trend Least Square untuk pajak kendaraan bermotor pada tahun 2016 sebesar Rp. 176.189.057.021 dan selalu meningkat tiap tahunnya sampai tahun 2020 sebesr Rp. 207.685.219.438. Untuk Penerimaan Bea balik nama pada tahun 2016 sebesar Rp. 176.334.894.949 dan tahun 2020 sebesr Rp. 197.897.953.080, Dengan ke 3 (tiga) metode tersebut yaitu Metode Moment, Metode Least Square dan trend kuadratik yang menunjukkan trend meningkat dari tahun 2016-2020, hal ini menunjukkan bahwa sumber PAD yang potensial diharapkan untuk Provinsi Bengkulu
\end{abstract}

\begin{abstract}
Karona Cahya Susena dan Ahmad Soleh; This study aims to describe the projection model in determining the Motor Vehicle income tax and transfer duties Dinas Pendapatan Daerah (Dispenda) Provinsi Bengkulu e in 2016-2020. The results of this study indicate that Trend Least Square method is more appropriately used to set targets in 2016-2020, where the calculation of trend Least Square for motor vehicle taxes in 2016 amounted to Rp. 176189057021 and is increasing each year until 2020 sebesr Rp. 207685219 438. Acceptance of transfer tax to the name in 2016 amounted to Rp. 176334894 949 and 2020 sebesr Rp. 197897953 080, with all three (3) such methods are Moment Method, Least Square method and quadratic trend that shows an increasing trend from year 2016 to 2020, it indicates that a potential source of revenue that is expected to Bengkulu Province.
\end{abstract}

Key Words: Motor Vehicle income tax and transfer duties

\section{PENDAHULUAN}

Provinsi Bengkulu termasuk Provinsi yang sedang berkembang di Indonesia. Dengan luas wilayah 1.978.870 hektar Provinsi Bengkulu terdiri dari 9 kabupaten dan 1 kota yaitu Kabupaten Bengkulu Selatan, Rejang Lebong, Bengkulu Utara, Kaur, Seluma, Muko-Muko, Lebong, Kepahiang, Bengkulu Tengah dan Kota Bengkulu.

Dengan adanya otonomi daerah menjadikan Provinsi Bengkulu mencari sumber-sumber penerimaan daerah yang biasa disebut Pendapatan Asli Daerah (PAD). PAD mempunyai salah satu komponen yaitu pajak daerah. Pajak daerah adalah pajak yang dipungut oleh pemerintah daerah baik daerah tingkat I (Pajak Provinsi) maupun daerah tingkat II (Pajak Kabupaten/ Kota) dan di guakan untuk membiayai rumah tangga daerah masing masing (Resmi, 2014:8).

Menurut Undang-undang No. 28 tahun 2009 tentang Pajak Daerah dan Restribusi Daerah, Pajak Daerah yang selanjutnya disebut adalah kontribusi wajib kepada Daerah yang terutang oleh orang pribadi atau badan yang bersifat memaksa berdasarkan Undang-Undang, dengan tidak mendapatkan imbalan secara langsung dan digunakan untuk keperluan Daerah bagi sebesar-besarnya kemakmuran rakyat.

Pajak bagi pemerintah daerah berperan sebagai sumber pendapatan (budgetary function) yang utama dan juga sebagai alat pengatur (regulatory function). Pajak sebagai salah satu sumber pendapatan daerah digunakan untuk membiayai pengeluaran-pengeluaran pemerintah. Melihat dari fenomena tersebut dapat diketahui pentingnya pajak bagi suatu daerah, terutama dalam menyokong pembangunan daerah itu sendiri dan merupakan pemasukan dana yang sangat potensial karena besarnya penerimaan pajak akan meningkat seiring laju pertumbuhan penduduk, perekonomian dan stabilitas politik. 
Dinas Pendapatan Daerah (DISPENDA) Provinsi Bengkulu adalah instansi pemerintah yang memiliki tugas pokok antara lain untuk melaksanakan segala usaha kegiatan pemungutan, pengumpulan dan pemasukan pendapatan daerah kedalam kas daerah secara maksimum baik terhadap daerah yang ada maupun dengan penggalian sumber sumber pendapatan daerah berdasarkan kebijakan yang ditetapkan oleh Gubernur atau peraturan perundang-undangan yang berlaku.

Pajak Kendaraan Bermotor (PKB) dan Bea Balik Nama Kendaraan Bermotor (BBN-KB) Provinsi Bengkulu merupakan sumber pendapatan daerah yang terbesar dan selalu mengalami peningkatan dari tahun ke tahun. Data yang di peroleh ditunjukkan pada tabel 1. Dan tabel 2. Di bawah ini:

Tabel 1. Penerimaan Pajak Kendaraan Bermotor (PKB) Provinsi Bengkulu Tahun 2008-2015

\begin{tabular}{|c|c|c|c|c|}
\hline Tahun & Target & Realisasi & $\%$ & Keterangan \\
\hline 2008 & 57.570 .000 .000 & 60.462 .207 .000 & 105,02 & Over Target \\
\hline 2009 & 71.240 .625 .600 & 69.937 .089 .500 & 98,17 & Under Target \\
\hline 2010 & 76.070 .321 .000 & 83.783 .056 .000 & 110,14 & Over Target \\
\hline 2011 & 86.415 .257 .199 & 105.647 .588 .004 & 122,26 & Over Target \\
\hline 2012 & 115.421 .852 .500 & 127.547 .813 .000 & 110,51 & Over Target \\
\hline 2013 & 135.242 .059 .261 & 143.333 .492 .500 & 105,98 & Over Target \\
\hline 2014 & 145.766 .827 .425 & 154.415 .048 .500 & 105,93 & Over Target \\
\hline 2015 & 149.978 .433 .212 & 160.447 .563 .000 & 106.98 & Over Target \\
\hline
\end{tabular}

Sumber: Dinas Pendapatan Daerah Provinsi Bengkulu, 2015

Tabel 2. Penerimaan Bea Balik Nama Kendaraan Bermotor (BBN-KB) Provinsi Bengkulu Tahun 20082015

\begin{tabular}{|c|c|c|c|l|}
\hline Tahun & Target & Realisasi & $\%$ & \multicolumn{1}{|c|}{ Keterangan } \\
\hline 2008 & 99.907 .964 .332 & 93.872 .427 .500 & 93,96 & Under Target \\
\hline 2009 & 110.798 .668 .603 & 76.504 .014 .500 & 69,05 & Under Target \\
\hline 2010 & 110.798 .668 .603 & 112.177 .688 .000 & 101,24 & Over Target \\
\hline 2011 & 124.557 .311 .526 & 161.198 .838 .000 & 129,42 & Over Target \\
\hline 2012 & 168.914 .311 .500 & 157.391 .381 .000 & 93,18 & Under Target \\
\hline 2013 & 168.914 .311 .500 & 158.552 .513 .000 & 93,87 & Under Target \\
\hline 2014 & 168.914 .311 .500 & 165.927 .542 .000 & 98,23 & Under Target \\
\hline 2015 & 163.185 .077 .507 & 140.045 .825 .500 & 85,82 & Under Target \\
\hline
\end{tabular}

Sumber: Dinas Pendapatan Daerah Provinsi Bengkulu, 2015

Dari tabel 1. Diatas dapat dilihat bahwa realisasi Pajak Kendaraan Bermotor (PKB) dari tahun 2008 sampai tahun 2015 selalu mengalami peningkatan. Dengan meningkatnya penerimaan Pajak Kendaraan Bermotor menunjukkan pemilikan kendaraan bermotor di Provinsi Bengkulu selalu meningkat dari tahun ke tahun. Melihat perkembangan pada tabel 2. Dari tahun ketahun secara rata-rata menunjukkan tidak tercapainya target penerimaan Bea Balik Nama Kendaraan Bermotor.

Dari data Perbandingan Realisasi dan Target Pajak PKB dan BBN-KB Tahun 2008-2015. Data tahun 2008 - 2015 merupakan data yang perlu di lakukan perbaikan dimana kendaraan bermotor, mobil, truk yang masih belum terdata yang seharusnya menjadi objek pajak dan banyaknya kendaraan bermotor yang menetap di provinsi bengkulu dengan palt luar kota yang belum melakuan balik nama atau sebagai pendapatan pajak bea balik nama.

Dalam rangka penyusunan APBD, DISPENDA Provinsi Bengkulu harus menghitung potensi sumber-sumber pendapatan pajak daerah. Salah satu sumber pendapatan daerah adalah Pajak Kendaraan Bermotor (PKB) dan Bea Balik Nama Kendaraan Bermotor (BBN-KB). Berdasarkan data tabel 1. Dan tabel 2. Perlu di lakukan kajian untuk mengetahui proyeksi pendapatan pajak daerah khususnya Pajak Kendaraan Bermotor (PKB) dan Bea Balik Nama Kendaraan Bermotor (BBN-KB) untuk 5 (Lima) tahun kedepan yaitu tahun 2016-2020.

Melihat kondisi yang terjadi di Provinsi Bengkulu tersebut tentunya sangat menarik untuk diteliti dan yang menjadi pokok permasalahan di dalam penelitian ini adalah model proyeksi dalam menentukan pendapatan pajak Kendaraan Bermotor dan Bea Balik Nama di Dinas Pendapatan Daerah (Dispenda) Provinsi Bengkulu tahun 2016-2020. 


\section{LANDASAN TEORI}

Pajak

Pajak menurut Undang - Undang Nomor 16 Tahun 2009, Pasal 1 ayat (1) Pajak adalah kontribusi wajib kepada Negara yang terutang oleh orang pribadi ataubadan yang bersifat memaksa berdasarkan Undang-Undang dengan tidak mendapatkan imbalan secara langsung dan digunakan untuk keperluan Negara bagisebesar-besarnya kemakmuran rakyat.

Menurut Prof. Dr. Rochmat Sumitro, SH (Mardiasmo, 2013:1) bahwa pajak merupakan iuran rakyat pada kas negara berdasarkan Undang-Undang (yang dapat di paksakan) dengan tiada mendapat jasa timbal (kontraprestasi) yang langsung dapat di tunjukkan dan yang di gunakan untuk membayar pengeluaran umum. Pajak menurut S. I. Djajadinigrat (Resmi, 2014: 1) adalah sebagai suatu kewajiban menyerahkan sebagian dari kekayaan ke kas Negarayang disebabkan suatu keadaan, kejadian, dan perbuatan yang memberikan kedudukan tertentu, tetapi bukan sebagai hukuman, menurut peraturan yangditetapkan Pemerintah serta dapat dipaksakan tetapi tidak ada jasa timbal balik dari Negara secara langsung, untuk memelihara kesejahteraan secara umum. Pendapat lain tentang pengertian pajak di kemukakan oleh Dr. N. J. Fedelmann (Resmi, 2014: 2) menyatakan prestasi yang dipaksakan sepihak oleh dan terutang kepada penguasa (menurut norma-norma yang ditetapkannya secara umum), tanpa adanya kontraprestasi, dan semata-mata digunakan untuk menutup pengeluaran-pengeluaran umum.

Dari pengerian di atas ciri-ciri yang melekat pada pengertian pajak adalah sebagai berikut:

1. Pajak di pungut berdasarkan Undang-Undang

2. Jasa timbal tidak di tunjukkan secara langsung

3. Pajak dipungut oleh pemerintah,baik pemerintah pusat maupun pemerintah daerah.

4. Diperuntukkan bagi pengeluaran - pengeluaran pemerintah (jika surplus digunakan untuk public saving). (Susena, 2015:97)

\section{Pajak Daerah}

Pajak Daerah menurut Pasal 1 Undang-undang Nomor 28 Tahun 2009 menyatakan kontribusi wajib kepada Daerah yang terutang oleh orang pribadi atau badan yang bersifat memaksa berdasarkan Undang-Undang, dengan tidak mendapatkan imbalan secara langsung dan digunakan untuk keperluan Daerah bagi sebesar-besarnya kemakmuran rakyat.

Dengan demikian pajak daerah adalah iuran wajib pajak kepada daerah untuk membiayai pembangunan daerah. Pajak Daerah ditetapkan dengan undang-undang yang pelaksanaannya untuk di daerah diatur lebih lanjut dengan peraturan daerah. Pemerintah daerah dilarang melakukan pungutan selain pajak yang telah ditetapkan undang-undang (Pasal 2 Undang-Undang Nomor 28 Tahun 2009).

Pajak yang di kelola pemerintah daerah baik Provinsi maupun kabupaten/ kota dapat dilihat pada tabel 3. Dibawah ini:

Tabel 3. Jenis-Jenis Pajak yang Dikelola Pemerintah Daerah

\begin{tabular}{|l|l|}
\hline \multicolumn{1}{|c|}{ Pajak Provinsi } & \multicolumn{1}{|c|}{ Pajak Kabupaten/Kota } \\
\hline Pajak Kendaraan Bermotor & Pajak Hotel \\
Bea Balik Nama Kendaraan Bermotor & Pajak Restoran \\
Pajak Bahan Bakar Kendaraan & Pajak Hiburan \\
Bermotor & Pajak Reklame \\
Pajak Air Permukaan & Pajak Penerangan Jalan \\
Pajak Rokok & Pajak Mineral Bukan Logam dan Batuan \\
& Pajak Parkir \\
& Pajak Air Tanah \\
& Pajak Sarang Burung Walet \\
& Pajak Bumi dan Bangunan Perdesaan dan \\
& Perkotaan \\
& Bea Perolehan Hak Atas Tanah dan Bangunan \\
\hline
\end{tabular}

Sumber: Undang-Undang No 28 Tahun 2009

\section{Pajak yang Dikelola Provinsi}

Ada lima jenis pajak yang dikelola oleh provinsi yaitu Pajak Kendaraan Bermotor, Bea Balik Nama Kendaraan Bermotor, Pajak Bahan Bakar Kendaraan Bermotor, Pajak Air Permukaan dan Pajak Rokok.

1) Pajak Kendaraan Bermotor 
Pajak Kendaraan Bermotor adalah pajak atas kepemilikan dan/atau penguasaan kendaraan bermotor. Kendaraan bermotor adalah semua kendaraan beroda beserta gandengannya yang digunakan di semua jenis jalan darat, dan digerakkan oleh peralatan teknik berupa motor atau peralatan lainnya yang berfungsi untuk mengubah suatu sumber daya energi tertentu menjadi tenaga gerak kendaraan bermotor yang bersangkutan, termasuk alat-alat berat dan alat-alat besar yang dalam operasinya menggunakan roda dan motor dan tidak melekat secara permanen serta kendaraan bermotor yang dioperasikan di air (Pasal 1 Undang-Undang Nomor 28 Tahun 2009).

2) Bea Balik Nama Kendaraan Bermotor

Bea Balik Nama Kendaraan Bermotor adalah pajak atas penyerahan hak milik kendaraan bermotor sebagai akibat perjanjian dua pihak atau perbuatan sepihak atau keadaan yang terjadi karena jual beli, tukar menukar, hibah, warisan, atau pemasukan ke dalam badan usaha (Pasal 1 Undang-Undang Nomor 28 Tahun 2009).

3) Pajak Bahan Bakar Kendaraan Bermotor

Pajak Bahan Bakar Kendaraan Bermotor adalah pajak atas penggunaan bahan bakar kendaraan bermotor. Bahan bakar kendaraan bermotor adalah semua jenis bahan bakar cair atau gas yang digunakan untuk kendaraan bermotor (Pasal 1 Undang-Undang Nomor 28 Tahun 2009). Tarif Pajak Bahan Bakar Kendaraan Bermotor ditetapkan paling tinggi sebesar 10\% (sepuluh persen). Khusus tarif Pajak Bahan Bakar Kendaraan Bermotor untuk bahan bakar kendaraan umum dapat ditetapkan paling sedikit 50\% (lima puluh persen) lebih rendah dari tarif Pajak Bahan Bakar Kendaraan Bermotor untuk kendaraan pribadi (Pasal 19 Undang-Undang Nomor 28 Tahun 2009).

4) Pajak Air Permukaan

Menurut Undang-Undang Nomor 28 Tahun 2009 Tentang Pajak Daerah dan Retribusi Daerah, Pajak Air Permukaan adalah pajak atas pengambilan dan/atau pemanfaatan air permukaan. Air permukaan adalah semua air yang terdapat pada permukaan tanah, tidak termasuk air laut, baik yang berada di laut maupun di darat. Tarif Pajak Air Permukaan ditetapkan paling tinggi sebesar 10\% (Pasal 24 Undang-Undang nomor 28 Tahun 2009).

5) Pajak Rokok

Menurut Undang-Undang Nomor 28 Tahun 2009 Tentang Pajak Daerah dan Retribusi Daerah, Pajak Rokok adalah pungutan atas cukai rokok yang dipungut oleh Pemerintah. Tarif Pajak Rokok ditetapkan sebesar 10\% (sepuluh persen) dari cukai rokok. Pajak Rokok dikenakan atas cukai rokok yang ditetapkan oleh Pemerintah (Pasal 29 Undang-Undang Nomor 28 Tahun 2009).

Penerimaan pajak rokok, baik bagian Provinsi maupun bagian Kabupaten/kota, dialokasikan paling sedikit $50 \%$ untuk mendanai pelayanan kesehatan masyarakat dan penegakan hukum oleh aparat yang berwenang ( Pasal 31 Undang-Undang Nomor 28 Tahun 2009).

\section{Pajak Kendaraan Bermotor}

Pajak Kendaraan Bermotor Semula sesuai dengan UU No. 18 tahun 1997 ditetapkan Pajak Kendaraan Bermotor, dimana pajak atas PKB (Pajak Kendaraan Bermotor) \& PKAA (Pajak Kendaraan Diatas Air) dicakupkan. Seiring dengan perubahan UU No. 18 tahun 1997 menjadi UU No. 34 tahun 2000, terminologi kendaraan bermotor diperluas dan dilakukan pemisahan secara tegas menjadi Kendaraan Bermotor dan di Kendaraan Atas Air. Hal ini membuat Pajak Kendaraan Bermotor diperluas menjadi PKB \& PKAA. Dalam praktiknya jenis pajak ini sering di bagi atas 2, yaitu PKB dan PKAA. Hal ini wajar saja mengingat kendaraan bermotor pada dasarnya berbeda dengan kendaraan di atas air. Pengenaan PKB \& PKAA tidak mutlak ada pada seluruh daerah provinsi di indonesia. Hal ini berkaitan dengan kewenangan yang diberikan kepada pemerintah provinsi untuk mengenakan atau tidak mengenakan suatu jenis pajak provinsi. Untuk dapat dipungut pada suatu daerah provinsi pemerintah daerah harus terlebih dahulu menerbitkan Peraturan Daerah tentang PKB, yang akan menjadi landasan hukum operasional dalam teknis pelaksanaan pengenaan dan pemungutan PKB \& PKAA didaerah provinsi yang bersangkutan. Pemerintah provinsi diberi kebebasan untuk menetapkan apakah PKB ditetapkan dalam satu peraturan daerah atau ditetapkan dalam dua peraturan daerah terpisah.

Pajak Kendaraan Bermotor (PKB) adalah pajak atas kepemilikan atau penguasaan kendaraan bermotor (kendaraan beroda dua atau lebih beserta gandengannya yang digunakan di semua jenis jalan darat dan digerakkan oleh peralatan teknik berupa motor atau peraltan lainnya yang berfungsi untuk mengubah suatu sumber daya energi tertentu menjadi tenaga gerak kendaraan bermotor yang bersangkutan, termasuk alat-alat besar yang bergerak).

Dasar Hukum Pajak Kendaraan Bermotor Dasar hukum pajak kendaraan bermotor diatur dalam :

1. Undang-Undang Nomor 34 tahun 2000 yang merupakan perubahan atas Undang-Undang Nomor 18 tahun 1997 tentang Pajak Daerah dan Retribusi Daerah.

2. Peraturan Pemerintah Nomor 65 tahun 2001 tentang Pajak Daerah. 
3. Peraturan daerah provinsi yang mengatur tentang PKB. Peraturan daerah ini dapat menyatu, yaitu satu peraturan daerah untuk PKB, tetapi dapat juga dibuat secara terpisah misalnya Peraturan Daerah tentang PKB.

4. Peraturan Menteri Dalam Negeri Nomor 2 tahun 2006 tentang Perhitungan Dasar Pengenanan Pajak Kendaraan Bermotor dan Bea Balik Nama Kendaraan Bermotor Tahun 2006.

5. Peraturan Gubernur yang mengatur tentang PKB sebagai aturan pelaksanaan peraturan daerah tentang PKB pada provinsi yang dimaksud.

Objek dan Wajib Pajak Kendaraan Bermotor Objek Pajak Kendaraan Bermotor adalah kepemilikan atau penguasaa kendaraan bermotor yang digunakan di semua jenis jalan darat seperti kawasan : 1 . Bandara 2. Pelabuhan laut 3. Perkebunan 4. Kehutanan 5. Pertanian 6. Pertambangan 7. Industri 8. Perdagangan 9. Sarana olah raga dan rekreasi

Wajib Pajak adalah orang pribadi atau badan yang memiliki kendaraan bermotor, jika wajib pajak merupakan badan maka kewajiban perpajakannya diwakili oleh pengurus atau kuasa hukum badan tersebut. Dengan demikian, pada PKB subjek pajak sama dengan wajib pajak, yaitu orang pribadi atau badan yang memiliki atau menguasai kendaraan bermotor.

Tarif Pajak Kendaraan Bermotor pribadi menurut Pasal 6 Undang-Undang Nomor 28 Tahun 2009 Tentang Pajak Daerah dan Retribusi Daerah ditetapkan sebagai berikut :

a. Untuk kepemilikan kendaraan bermotor pertama paling rendah sebesar 1\% (satu persen) dan paling tinggi sebesar $2 \%$ (dua persen);

b. Untuk kepemilikan kendaraan bermotor kedua dan seterusnya tarif dapat ditetapkan secara progresif paling rendah sebesar $2 \%$ (dua persen) dan paling tinggi sebesar 10\% (sepuluh persen).

Sedangkan tarif Pajak Kendaraan Bermotor angkutan umum, ambulans, pemadam kebakaran, sosial keagamaan, lembaga sosial dan keagamaan, Pemerintah/TNI/POLRI, Pemerintah Daerah, dan kendaraan lain yang ditetapkan dengan Peraturan Daerah, ditetapkan paling rendah sebesar $0,5 \%$ (nol koma lima persen) dan paling tinggi sebesar 1\% (satu persen). Kemudian Tarif Pajak Kendaraan Bermotor alat-alat berat dan alat-alat besar ditetapkan paling rendah sebesar 0,1\% (nol koma satu persen) dan paling tinggi sebesar $0,2 \%$ (nol koma dua persen).

\section{Bea Balik Nama Kendaraan Bermotor}

Bea Balik Nama Kendaraan Bermotor (BBN-KB) dalam adalah pajak atas penyerahan hak milik kendaraan bermotor sebagai akibat perjanjian dua belah pihak atau perbuuatan sepihak atau keadaan yang terjadi karena jual beli, tukar menukar, hibah, warisan, atau pemasukan ke badan usaha. (Peraturan Menteri Dalam Negeri Republik Indonesia Nomor 101 Tahun 2014).

Obyek BBN-KB Adalah penyerahan Kendaraan Bermotor, yaitu pengalihan hak milik Kendaraan Bermotor sebagai akibat perjanjian dua pihak atau perbuatan sepihak atau keadaan yang terjadi karena jual beli, tukar menukar, hibah termasuk hibah wasiat dan hadiah, warisan, atau pemasukan ke dalam Badan Usaha. sedangkan Subyek BBN-KB Adalah orang pribadi atau badan yang menerima penyerahan Kendaraan Bermotor (KBM).

Menurut Pasal 12 Undang-Undang Nomor 28 Tahun 2009 Tentang Pajak Daerah dan Retribusi Daerah tarif Bea Balik Nama Kendaraan Bermotor ditetapkan paling tinggi masing-masing sebagai berikut :

a. Penyerahan pertama sebesar $20 \%$ (dua puluh persen) dan

b. Penyerahan kedua dan seterusnya sebesar $1 \%$ (satu persen).

Khusus untuk kendaraan bermotor alat-alat berat dan alat-alat besar yang tidak menggunakan jalan umum tarif pajak ditetapkan paling tinggi masing-masing sebagai berikut :

a. Penyerahan pertama sebesar 0,75\% (nol koma tujuh puluh lima persen);

b. Penyerahan kedua dan seterusnya sebesar $0,075 \%$ (nol koma nol tujuh puluh lima persen).

\section{KERANGKA ANALISIS}

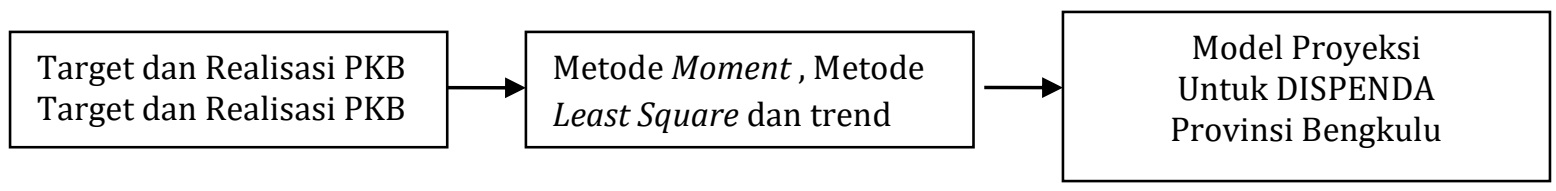

Gambar 1. Kerangka Analisis

\section{METODOLOGI}

Jenis penelitian adalah deskriptif kuantitatif. Analisis Deskriptif maksudnya memberikan gambaran tentang perkembangan komponen Pajak Daerah di Provinsi Bengkulu studi dari waktu ke 
waktu menurut jenis komponen dari pos Pajak Daerah serta gambaran taget dan realisasinya. Sedangkan Analisis Kuantitatif digunakan untuk memperoleh proyeksi dari Pajak Daerah.

Metode-Metode dalam Peramalan (Forecast) menghendaki perpaduan antara pendekatan kuantitatif dengan menggunakan teknik statistika maupun matematis. Teknik statistika dan matematis dipakai sebagai alat primer dalam penyusunan peramalan, sedangkan pendapat dipakai sebagai pelengkap. secara sistematis metode forecast ada 3 teknik dalam metode matematis yang digunakan, yaitu:

\section{Metode Moment}

Rumus dasar yang digunakan disini:
a. $Y=a+b x$
b. $\sum Y \mathrm{i}=\mathrm{n} \cdot \mathrm{a}+\mathrm{b} \sum \mathrm{xi}$
c. $X i . Y i=a \sum x i+b \sum x i^{2}$

\section{Metode Least Square}

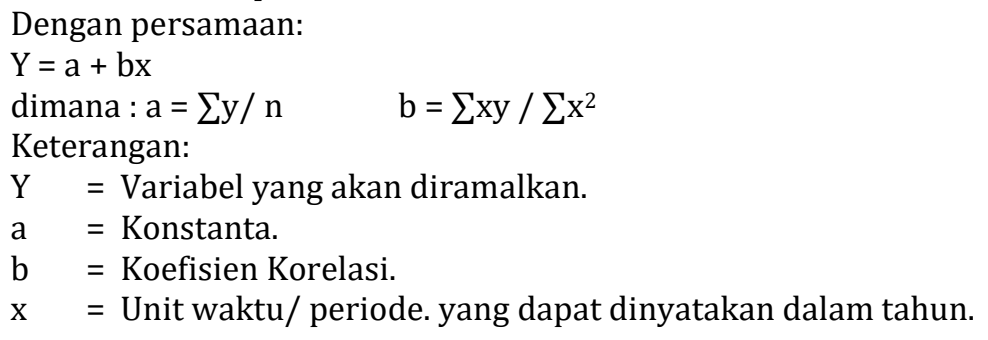

\section{Metode Kuadratik}

Rumus yang digunakan dalam metode ini adalah:

$\mathrm{Y}=\mathrm{a}+\mathrm{bX}+\mathrm{c}(\mathrm{X})^{2}$

Dimana:

$\sum \mathrm{Y}=\mathrm{n} \cdot \mathrm{a}+\mathrm{c} \cdot \sum \mathrm{X}^{2}$

$\sum X Y=b \cdot \sum X^{2}$

$\sum \mathrm{X}^{2} \mathrm{Y}=\mathrm{a} \cdot \sum \mathrm{X}^{2}+\mathrm{c} \cdot \sum \mathrm{X}^{4}$

Syarat $\sum \mathrm{X}=0$

$$
\mathrm{a}=\frac{\left(\sum Y\right)\left(\sum x^{4}\right)-\left(\sum x^{2} Y\right)\left(\sum x^{2}\right)}{n\left(\sum x^{4}\right)-\left(\sum x^{2}\right)^{2}} \mathrm{~b}=\frac{\sum X Y}{\sum x^{2}} \mathrm{c}=\frac{n\left(\sum x^{2} Y\right)-\left(\sum x^{2}\right)\left(\sum Y\right)}{n\left(\sum x^{4}\right)-\left(\sum x^{2}\right)^{2}}
$$

\section{HASIL DAN PEMBAHASAN \\ Model Proyeksi Untuk Dinas Pendapatan Daerah Provinsi Bengkulu}

Berdasarkan hasil penelitian dalam rentang 8 tahun yang telah dilakukan di atas maka dapat dilihat bahwa selama 5 tahun kedepan, pendapatan dari pajak kendaraan bermotor dan bea balik nama kendaraan bermotor dari hasil penelitian menggunakan 3 (tiga) metoode Peramalan yaitu Metode Moment , Metode Least Square dan trend kuadratik yang menunjukkan trend meningkat dari tahun 20162020. Hal ini tidak lepas dari semakin tingginya tingkat kebutuhan terhadap kendaraan bermotor dari tahun ke tahunnya. Saat ini kendaraan bermotor sudah beralih dari barang mewah menjadi barang primer atau barang yang paling di butuhkan di kehidupan masyarakat kota Bengkulu. Hal ini dibuktikan juga dengan semakin mudahnya kendaraan bermotor untuk di dapatkan oleh masyarakat.

Dengan penelitian ini maka dapat dilihat perbandingan dengan menggunakan ketiga metode peramalan untuk menentukan target pendapatan dari pajak kendaraan bermotor dan bea balik nama kendaraan bermotor yang realistis dan dapat di capai oleh Dinas Pendapatan Daerah Provinsi Bengkulu.

Penentuan metode untuk menetapkan target yang kan dicapai baik target untuk pajak kendaraan bermotor maupun bea balik nama kendaraan bermotor dengan melihat data yang telah di peroleh selama 8 tahun untuk kedua target tersebut mengalami naik dan turun. Peneliti menyarankan untuk penetapan target pajak kendaraan bermotor maupun bea balik nama kendaraan bermotor menggunakan Metode Least Square dimana dapat dibandingkan pada tabel 4. dan tabel 5. dibawah ini: 
Tabel 4. Perhitungan Target Pendapatan Pajak Kendaraan Bermotor

\begin{tabular}{|c|c|c|c|}
\hline Tahun & Metode Moment & Trend Least Square & Metode Kuadratik \\
\hline 2016 & 184.063 .097 .625 & 176.189 .057 .021 & 294.115 .179 .999 \\
\hline 2017 & 199.811 .178 .834 & 184.063 .097 .625 & 350.071 .128 .354 \\
\hline 2018 & 215.559 .260 .042 & 191.937 .138 .229 & 411.596 .727 .073 \\
\hline 2019 & 231.307 .341 .250 & 199.811 .178 .834 & 478.691 .976 .155 \\
\hline 2020 & 247.055 .422 .458 & 207.685 .219 .438 & 551.356 .875 .602 \\
\hline
\end{tabular}

Tabel 5. Perhitungan Target Penerimaan Bea Balik Nama Kendaraan Bermotor

\begin{tabular}{|c|c|c|c|}
\hline Tahun & Metode Moment & Trend Least Square & Metode Kuadratik \\
\hline 2016 & 181.725 .659 .482 & 176.334 .894 .949 & 238.487 .264 .595 \\
\hline 2017 & 192.507 .188 .548 & 181.725 .659 .482 & 257.093 .186 .238 \\
\hline 2018 & 203.288 .717 .613 & 187.116 .424 .015 & 275.009 .030 .264 \\
\hline 2019 & 214.070 .246 .679 & 192.507 .188 .548 & 292.234 .796 .673 \\
\hline 2020 & 224.851 .775 .744 & 197.897 .953 .080 & 308.770 .485 .465 \\
\hline
\end{tabular}

Dengan membandingan data perhitungan target untuk tahun 2016 sampai 2020 baik untuk Pajak Kendaraan Bermotor maupun Bea Balik Nama Kendaraan Bermotor metode Trend Least Square lebih tepat pada kondisi di provinsi bengkulu. Dengan adanya target yang ditentuka juga harus didukung oleh perbaikan sistem administrasi, peningkatan SDM petugas pajak dan sistem pengelolaan yang baik yang berdampak penyerdehanaan prosedur pembayaran pajak kendaraan bermotor.

\section{KESIMPULAN}

Berdasar pembahasan yang telah diuraian sebelumnya, kesimpulan yang dapat diambil dari penelitian ini adalah:

1. Metode Trend Least Square lebih tepat di gunakan untuk menetapkan target tahun 2016-2020, dimana perhitungan trend Least Square untuk pajak kendaraan bermotor pada tahun 2016 sebesar Rp. 176.189.057.021 dan selalu meningkat tiap tahunnya sampai tahun 2020 sebesr Rp. 207.685.219.438. Untuk Penerimaan Bea balik nama pada tahun 2016 sebesar Rp. 176.334.894.949 dan tahun 2020 sebesr Rp. 197.897.953.080

2. Dengan ke 3 (tiga) metode tersebut yaitu Metode Moment, Metode Least Square dan trend kuadratik yang menunjukkan trend meningkat dari tahun 2016-2020, hal ini menunjukkan bahwa sumber PAD yang potensial diharapkan untuk Provinsi Bengkulu.

\section{Saran}

Dari Hasil penelitian maka dapat peneliti mensarankan sebagai berikut:

1. Dengan adanya target yang ditentuka juga harus didukung oleh perbaikan sistem administrasi, peningkatan SDM petugas pajak dan sistem pengelolaan yang baik yang berdampak penyerdehanaan prosedur pembayaran pajak kendaraan bermotor.

2. Dengan adanya perhitungan target dari tahun 2016 sampai dengan 2020 dapat sebagai perbandingan atau acuan untuk Dinas Pendapatan Daerah Provinsi Bengkulu dalam pelaksanaan penentuan target pajaknya.

\section{DAFTAR PUSTAKA}

Eryandi, Gusti, 2011, Analisis Efektivitas Pemungutan Pajak Kendaraan Bermotor Dan Bea Balik Nama Kendaraan Bermotor Dalam Meningkatkan Pendapatan Asli Daerah (PAD) Di Provinsi Bengkulu, Jurnal Ekonomi Dan Perencanaan Pembangunan Universitas Bengkulu, Vol. 4 No. 02 Juli Desember 2011

M. Nafarin, 2000, “Penganggaran Perusahaan”, Edisi Pertama, Salemba Empat, Jakarta.

Mardiasmo, 2013, Perpajakan. Edisi Revisi. Yogyakarta. Penerbit Andi

Peraturan Daerah Provinsi Bengkulu Nomor 6 Tahun 2014 Tentang Pajak Daerah Provinsi Bengkulu 
Peraturan Menteri dalam Negeri Republik Indonesia Nomor 101 Tahun 2014 tentang Perhitungan Dasar Pengenaan Pajak Kendaraan Bermotor Dan Bea Balik Nama Kendaraan Bermotor Tahun 2015

Resmi, Siti, 2014, Perpajakan: Teori Dan Kasus, Edisi 8, Buku 1, Salemba Empat, Jakarta

Susena, C., Karona, 2015, Potensi Penerimaan Pajak Bumi Dan Bangunan Di Kota Bengkulu, Jurnal Ilmiah Ekonomi dan Bisnis "Ekombis Review" Universitas Dehasen Bengkulu, Volume 3 Nomor 1, Januari 2015

Undang-undang No. 28 tahun 2009 tentang Pajak Daerah dan Restribusi Daerah. 